\title{
Culture and Conceptualisation of Scientific Terms: An Analysis of the Concepts "Weight" and "Mass" in Arabic and French
}

\author{
*HICHAM LAHLOU \\ HAJAR ABDUL RAHIM \\ School of Humanities, Universiti Sains Malaysia, \\ 11800 USM Pulau Pinang, Malaysia \\ *Corresponding author: hlahlou2003@ hotmail.com
}

Published online: 30 December 2016

To cite this article: Hicham Lahlou and Hajar Abdul Rahim. 2016. Culture and conceptualisation of scientific terms: An analysis of the concepts "weight" and "mass" in Arabic and French. KEMANUSIAAN the Asian Journal of Humanities 23(Supp. 2): 19-37, https://doi.org/10. 21315/kajh2016.23.s2.2

To link to this article: https://doi.org/10.21315/kajh2016.23.s2.2

\begin{abstract}
Studies on difficulties in understanding scientific terms have shown that the problem is more serious among non-Western learners. The main reasons for this are the learners' pre-existing knowledge of scientific terms, their native language incommensurability with Western languages, and the polysemy of the words used to denote scientific concepts. The current study is an analysis of the conceptualisation of scientific concepts in two culturally different languages, i.e. Arabic and French, which represent a non-Western language and a Western language respectively. Physics concepts which are considered as some of the most challenging concepts for non-Western languages (Loo 2005; Aranador 2005) were selected for analysis. To this end, the terms that refer to two physics

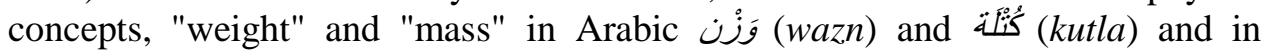
French poids and masse were semantically analysed. The analysis of the concepts in both languages is informed by the prototype theory by Rosch $(1973 ; 1975)$, idealised cognitive models (ICMs) by Lakoff (1987), and conceptual metaphor and conceptual metonymy by Lakoff and Johnson (2003). The data for analysis were retrieved from two comparable Arabic and French corpora, namely the ArabiCorpus and the Concordancier-Corpus Français. The results suggest that there are both similarities and differences between the Arabic and French concepts in terms of meanings, prototypes, and metaphorical as well as metonymic semantic extensions. These findings support the argument that the human conceptual system is related to our environmental and cultural experiences and also importantly, validate previous claims on the need for
\end{abstract}


educators to be cognizant of the culturally relevant meanings of scientific words found in everyday language that may impede learners' understanding of scientific concepts.

Keywords and phrases: culture, conceptualisation, polysemy, prototype, conceptual metaphor, metonymy

\section{Introduction}

In his discussion on language and thought, Hudson (1996) states that culture is a socially acquired knowledge. This knowledge is reflected in the language that we use because most of language is contained within culture. Given that our conceptualisation is dictated by our environment and experiences, the value of our language or sign-system ${ }^{1}$ is therefore culture-specific. This is because as language users, we are the active makers of meanings and the value that we agree to incorporate in a sign is often guided by the codes of our culture. This concurs with Sharifian's argument that "Human conceptualisation is as much a cultural as it is an individual phenomenon" $(2011,3)$ which suggests that conceptualisation may begin in an individual but could spread to a whole culture. According to Sharifian "cultural conceptualisations, embody group-level cognitive systems such as worldviews" $(2011,5)$ and they emerge from the exchanges among members of a culture. These conceptualisations which are "negotiated and renegotiated across generations" (Sharifian 2011, 17) are most evident in lexis. This point brings the discussion to the current concern of the study on the conceptualisation of scientific concepts in different cultures.

Studies have shown that despite their prevalence in everyday speech, words such as "temperature", "energy" and "nature" have been found to be difficult to understand when they are learned as scientific concepts. Past studies (e.g., Kawasaki 1996; Ogawa 1998; Kawasaki 1999; 2002; 2007; Aikenhead and Ogawa 2007; Ho-Abdullah and Hashim 2009; Lahlou and Hajar 2013) have shown that the main cause for the difficulty is learners' pre-existing knowledge of such terms. Learners' inclination to associate these words which are found in their everyday speech with their cultural, social and bodily experience may negatively affect their understanding of the terms as scientific concepts.

It has been suggested that Western learners may not face problems in learning science subjects regardless of the language used because Western languages belong to the same language family and relate to the Western social and cultural background. This follows Whorf's (1956) claim that there is a slight difference among European languages, with the exception of Balto-Slavic and non-IndoEuropean. Despite this, research has shown that both Western and non-Western 
learners face this problem, but the cognitive load differs between the two groups, given the differences in language. Western learners' challenge in understanding scientific concepts lies in the difference between everyday speech and scientific language (Duit and Kesidou 1988; Strömdahl 2007). However, for non-Western learners, the difficulty is compounded because scientific language is a Western language. Each of these languages has a specific socio-cultural load attached to it and is therefore associated with a distinct conceptual system which relies on and is closely related to humans' physical and cultural experience (Lakoff 1987).

To address the problems faced by learners, in some non-Western contexts, scientific terms are translated into the local language. However, studies on the translation of scientific terms from Western languages to other languages reveal that translation can be problematic as numerous real and physical phenomena can be conceptualised in different ways across languages (Boas 1911; 1922; Sapir 1921; Whorf 1956; Kawasaki 1996; 1999; 2002; 2007; Ogawa 1998; Aikenhead 2001). Notwithstanding the findings of these studies, there is still a gap in the field with regard to the philosophical, psychological and socio-cultural impact of learning science on learners of different ethnic groups (Loo 2005; $\mathrm{Ng}$ and Soo 2006). In the Arabic context for instance, there is very little understanding of the relationship between language and the learning of science. This is the motivation for the current study on the relationship between culture and conceptualisation, based on a semantic analysis of two physics concepts "weight" and "mass" in two different cultures, Arabic and French. For this purpose, the terms for "weight" and "mass" in Arabic that is, وَزْن (wazn) and (kutla) are compared to the French terms poids and masse in terms of their polysemy, prototypes metaphor and metonymy based on Lakoff's (1987) theory of Idealised Cognitive Model (ICM).

Based on earlier frameworks including Frame Semantics (Fillmore 1982), Conceptual Metaphor (Lakoff and Johnson 1980) and Cognitive Grammar (Langacker 1987), the notion of cognitive models suggests that human encyclopaedic knowledge is organised by means of ICMs. The idea of ICMs is that they organise human "experiences into complex structured wholes" (Lakoff 1987, 68). For instance, Lakoff (1987, 74-76) argues that the ICMs for "mother" include a composite of different ICMs including "birth", "genetic", "nurturance", "marital", "genealogical". This cluster of ICMs is therefore "a domain matrix" (Croft and Cruse 2004, 31) constituting the complex notion of "mother". And its representation begins with what is known as prototype, which is the most typical representative or example of a category (Rosch 1978). The centre of a cluster of similar objects is the prototype (Hampton 2006) and is usually the first model in the cluster of ICMs. Therefore in analysing a concept or category, the prototype should be identified. 
From a cognitive linguistics perspective, polysemy is a "radial category" of which the related meanings are subcategories that range from prototypical to peripheral subcategories or members. Polysemy is the outcome of the extension of idealised cognitive models (ICMs) (Lakoff 1987). As one meaning or subcategory can be more prototypical than another, it constitutes the source from which the other meanings are projected (Lakoff 1987). The extension of a word meaning is motivated by a cognitive mechanism, notably metaphor or metonymy (Lakoff and Johnson 2003).

As the polysemy, prototype, conceptual metaphor and conceptual metonymy of a concept are interconnected, an analysis of all these features is necessary for a complete understanding of its semantics. In the current study on "weight" and "mass" in Arabic and French, the findings on the polysemy, prototype and conceptual metaphor and metonymy of the concepts will shed light on their conceptualisation and the extent of their linguistic distinction in different cultures compared to their scientific meaning.

\section{Methodology}

The analysis of the concepts "weight" and "mass" in Arabic and French in the current study is based on data generated from two comparable Arabic and French corpora, the ArabiCorpus (Arabic Corpus Search Tool) and the ConcordancierCorpus Français. Bowker and Pearson (2002) argue that corpora can facilitate the exploration of the varied meanings of expressions based on real instances of language and offer more up-to-date real language. Thus, corpora do not only facilitate the task of identifying meanings but are also a source for real examples of language use. Corpora are also valuable in identifying the frequency of occurring collocates (Bowker and Pearson 2002) which is crucial in identifying the prototypical meanings of words that are being analysed (Geeraerts 2006). In the current study, the frequency of the collocates of and masse formed the data for the analysis of their prototypical meanings.

The ArabiCorpus comprises several subcorpora, namely newspapers $(135,360,804$ words), pre-modern texts $(9,127,331$ words), modern literature (1,026,171 words), Egyptian colloquialism (164,457 words) and non-fiction (27,945,460 words). The Concordancier-Corpus Francais consists of many subcorpora: newspapers (mainly, Le Monde [the World] [1,000,000 words], spoken French [150,000 words], written French [150,000 words], de Maupassant [collected works of de Maupassant, most of which are short stories] [3,000,000 words] and Corpatext [comprehensive corpora of words and texts] [37,000,000 words]). Both corpora (ArabiCorpus and the Concordancier-Corpus Francais) contain a large number of data, providing a rich data set which may cover all the 
senses of the words under study. As well, they contain a highly representative collection of collocates of the terms concerned.

The analysis of the data involves a few steps. First, the polysemy of the Arabic وَزْن (wazn) and astla) and the French poids and masse is analysed. This is achieved by identifying the different senses of each term that emerge from an analysis of the concordance data generated from the ArabiCorpus and the Concordancier-Corpus Francais. Second, the prototype of each concept is identified based on the frequency analysis of the collocates for وَ S (kutla) derived from the ArabiCorpus and those of poids and masse generated from the Concordancier-Corpus Francais. Finally, the semantic extension of each term is analysed based on the conceptual metaphor and conceptual metonymy that emerge in corpora.

\section{Results}

The results of the analysis of the concepts "weight" and "mass" in Arabic and French are presented in the following sections based on the different levels of analyses involving their polysemous meanings, prototypical meanings, metaphorical and metonymic extensions. The outcome of these analyses will provide an understanding of how the terms which are used as scientific terms are conceptualised in each language.

The polysemy, prototypical meanings, and metaphorical and metonymic extensions of

Firstly, the findings on the polysemous meanings of the terms derived from the ArabiCorpus and the Concordancier-Corpus Français, as well as examples of texts in which the particular meaning is used, are presented in Table 1 (translation of the examples are in square brackets). In total, 13 different senses were derived from the analysis of the concept "weight" in Arabic and French. However, as evident in the table, not all senses are available in both languages.

The data suggests that both "importance", "weight class" (in boxing) and "measurement of weight (of mass) of an individual's body". Besides these meanings, the Arabic term وَزْن (wazn) also possesses four other meanings i.e. "metre (in poetry)", "form (in morphology)", "a side of a mountain" and "wisdom". On the other hand, poids has five other meanings, i.e. "pressure (of atmosphere)", "responsibility", "heavy goods lorry", "the central energy storage device (of a clock)" and "metal object of a determined mass for weighing things on a scale" which do not seem to be available in the Arabic term. 
Table 1. The senses of $(w a z n)$ and poids derived from the ArabiCorpus and the Concordancier-Corpus Français

\begin{tabular}{|c|c|c|}
\hline \multirow{2}{*}{ Senses } & \multicolumn{2}{|l|}{ Examples } \\
\hline & Arabic & French \\
\hline \multirow[t]{2}{*}{$\begin{array}{l}\text { (1) "heaviness, } \\
\text { weighing" }\end{array}$} & 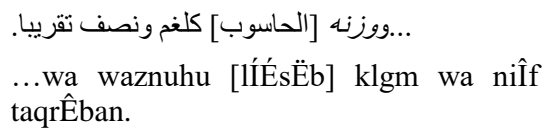 & $\begin{array}{l}\text {...il devait emporter un poids de } \\
\text { quatre mille livres... }\end{array}$ \\
\hline & $\begin{array}{l}\text { [...and its [computer's] weight is roughly } \\
\text { one and a half kilograms.] }\end{array}$ & $\begin{array}{l}\text { [...he had to carry a weight of } \\
\text { four thousand pounds...] }\end{array}$ \\
\hline \multirow[t]{2}{*}{$\begin{array}{l}\text { (2) } \\
\text { "importance, } \\
\text { influence" }\end{array}$} & 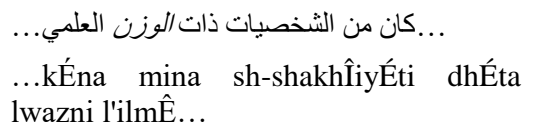 & $\begin{array}{l}\text {...ce n'est pas le nom de } \\
\text { l'écrivain qui donne du poids à } \\
\text { l'oeuvre, c'est son génie. }\end{array}$ \\
\hline & $\begin{array}{l}{[\ldots \text { he was a figure of a scientific }} \\
\text { weight... }\end{array}$ & $\begin{array}{l}{[\ldots \text { it is not the name of the }} \\
\text { writer that gives weight to the } \\
\text { work, it is his genius] }\end{array}$ \\
\hline \multirow[t]{3}{*}{$\begin{array}{l}\text { (3) "metre (in } \\
\text { poetry)" }\end{array}$} & وينسب له [يعرب] أنه كان أول من قال الشعر & NIL \\
\hline & $\begin{array}{l}\text { wa yunsabu lahu [ya'rubi] annahu kÉna } \\
\text { awwala man qÉla sh-shi'ra wa } \\
\text { waznahu... }\end{array}$ & \\
\hline & $\begin{array}{l}\text { [And he [Ya'rub] is credited with telling } \\
\text { poetry and its metre...] }\end{array}$ & \\
\hline \multirow{3}{*}{$\begin{array}{l}\text { (4) "weight } \\
\text { class (in } \\
\text { boxing)" }\end{array}$} & احرز الملاكم الاميركي مارك جونسون لقب بطل العالملية... & $\begin{array}{l}\text {...Clay est champion du monde } \\
\text { des poids lourds. }\end{array}$ \\
\hline & $\begin{array}{l}\text { aÍraza lmulÉkimu l'amrÊkÊ mÉrk } \\
\text { jonson laqaba baÏali l'Élami liwazni dh- } \\
\text { dhubÉba... }\end{array}$ & \\
\hline & $\begin{array}{l}\text { [The American boxer, Mark Johnson, } \\
\text { won the title of Fly weight World } \\
\text { Champion...] }\end{array}$ & $\begin{array}{l}\text { [...Clay is World Heavyweight } \\
\text { Champion] }\end{array}$ \\
\hline \multirow[t]{3}{*}{$\begin{array}{l}(5) \text { "form (in } \\
\text { morphology)" }\end{array}$} & ... تشبيها له بالفعل وزنا ومعنى خصوصا فعل & NIL \\
\hline & $\begin{array}{l}\text {...tashbÊhan lahu bilfi'li waznan wa } \\
\text { ma'nan khusËsan fi'la t-ta'ajjub... }\end{array}$ & \\
\hline & $\begin{array}{l}\text { [...by analogy with the verb in terms of } \\
\text { morphology and meaning, especially } \\
\text { exclamation verbs...] }\end{array}$ & \\
\hline
\end{tabular}


Table 1. (Continued)

\begin{tabular}{|c|c|c|}
\hline \multirow{2}{*}{ Senses } & \multicolumn{2}{|c|}{ Examples } \\
\hline & Arabic & French \\
\hline \multirow{3}{*}{$\begin{array}{l}\text { (6) "human } \\
\text { weight"/ } \\
\text { "measurement } \\
\text { of weight (of } \\
\text { mass) of the } \\
\text { body of an } \\
\text { individual" }\end{array}$} & ومع اهمال تطبيق الحمية المنصو الزح بهائد مشكلة كبيرة. & $\begin{array}{l}\text {...il commença à prendre du } \\
\text { poids... }\end{array}$ \\
\hline & $\begin{array}{l}\text { wa yusbiĺu ttakhallusu mina lwazni } \\
\text { zzÉ'idi ma'a murËri lwaqti wa ma'a } \\
\text { ihmÉli tä̈bÊqi líimyati lmansËÍí bihÉ } \\
\text { muskilatun kabÊra. }\end{array}$ & \\
\hline & $\begin{array}{l}\text { [And getting rid of weight excess, with } \\
\text { the passing of time and neglecting the } \\
\text { recommended diet, becomes a big } \\
\text { problem] }\end{array}$ & $\begin{array}{l}{[\ldots \text { he began to gain some }} \\
\text { weight... } \\
\text {...he began to gain weight...] }\end{array}$ \\
\hline \multirow[t]{3}{*}{$\begin{array}{l}\text { (7) "a side (of a } \\
\text { mountain)" }\end{array}$} & ...يتحول الى كتلة من الصخر فى وزن الجبل لايقوى & NIL \\
\hline & $\begin{array}{l}\text { yataÍawwalu ilÉ kutlatin mina Î̂akhri fế } \\
\text { wazni ljabal lÉ yaqwÉ 'alÉ raf'ihÉ aÍad. }\end{array}$ & \\
\hline & $\begin{array}{l}\text { [...it turns into a mass of rock on the } \\
\text { side of the mountain which Neg. one } \\
\text { can lift] }\end{array}$ & \\
\hline \multirow[t]{3}{*}{$\begin{array}{l}\text { (8) "sobriety, } \\
\text { wisdom" }\end{array}$} & ...كانت جهة الوساطة ذات وزن راجح وسمعة دولية & NIL \\
\hline & $\begin{array}{l}\text {.. kÉnat jihatu lwasÉÏati dhÉta waznin } \\
\text { rÉjilíin wa sum'atin dawliyatin Íasana... }\end{array}$ & \\
\hline & $\begin{array}{l}\text { [...the mediator was of sobriety and } \\
\text { good international reputation...] }\end{array}$ & \\
\hline \multirow[t]{2}{*}{$\begin{array}{l}\text { (9) "pressure } \\
\text { (of } \\
\text { atmosphere)" }\end{array}$} & NIL & 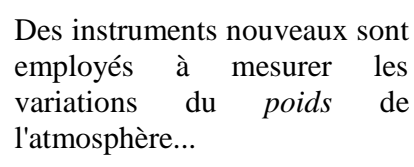 \\
\hline & & $\begin{array}{l}\text { [Some new instruments are } \\
\text { used to measure changes in the } \\
\text { pressure of the atmosphere...] }\end{array}$ \\
\hline \multirow[t]{2}{*}{$\begin{array}{l}\text { (10) "burden, } \\
\text { responsibility" }\end{array}$} & NIL & $\begin{array}{l}\ldots \text { [ces gens] passent le jour } \\
\text { courbés sous le poids des } \\
\text { affaires... }\end{array}$ \\
\hline & & $\begin{array}{l}\text { [...[these people] spend the day } \\
\text { bent under the weight of } \\
\text { affairs...] }\end{array}$ \\
\hline
\end{tabular}


Table 1. (Continued)

\begin{tabular}{|c|c|c|}
\hline \multirow{2}{*}{ Senses } & \multicolumn{2}{|c|}{ Examples } \\
\hline & Arabic & French \\
\hline \multirow{2}{*}{$\begin{array}{l}\text { (11) "heavy } \\
\text { goods lorry } \\
\text { (followed by } \\
\text { the adjective } \\
\text { lourd)" }\end{array}$} & \multirow[t]{2}{*}{ NIL } & $\begin{array}{l}\text {...une voiture de location avait } \\
\text { été aplatie Fem. par un poids } \\
\text { lourd... }\end{array}$ \\
\hline & & $\begin{array}{l}\text { [...a rental car had been } \\
\text { flattened by a truck on the } \\
\text { road...] }\end{array}$ \\
\hline \multirow{2}{*}{$\begin{array}{l}\text { (12) "weight, } \\
\text { the central } \\
\text { energy storage } \\
\text { device (of a } \\
\text { clock)" }\end{array}$} & \multirow[t]{2}{*}{ NIL } & $\begin{array}{l}\text {... [chaire] qui s'élevait vis-à-vis } \\
\text { d'une horloge à poids... }\end{array}$ \\
\hline & & $\begin{array}{l}{[\ldots \text { [seat }] \text { which was opposite a }} \\
\text { weight-driven clock...] }\end{array}$ \\
\hline $\begin{array}{l}\text { (13) "metal } \\
\text { object of a }\end{array}$ & \multirow[t]{2}{*}{ NIL } & $\begin{array}{l}\text { Justes poids et balances } \\
\text { exactes. }\end{array}$ \\
\hline $\begin{array}{l}\text { determined } \\
\text { mass for } \\
\text { weighing } \\
\text { things on a } \\
\text { scale" }\end{array}$ & & $\begin{array}{l}\text { [Right weights and accurate } \\
\text { scales] }\end{array}$ \\
\hline
\end{tabular}

The projection of the meanings of the terms concerned is motivated by cognitive mechanisms, particularly conceptual metaphor and conceptual metonymy. Therefore, to unravel the semantics of the concepts "weight" in Arabic and French, the polysemous senses of $َ$ (wazn) and poids, as presented in Table 1, are analysed in terms of their semantic extensions. These extensions are generally from structures in the physical or concrete domain to structures in abstract domains (Lakoff 1987).

The data suggests that evident in the example "he was a figure of a scientific weight" (Table 1, Meaning 2). In this example "weight", which is a physical quality or property, is projected to "importance", which is a quality. This semantic extension is motivated by "importance is weight" conceptual metaphor, which is part of "properties are physical properties" conceptual metaphor. Similarly, French poids (weight) is extended to include the sense "importance" in the example "it is not the name of the writer that gives weight to the work, it's his genius" (Table 1, Meaning 2). In this example, "weight", the source domain, is mapped onto "importance", target domain. Therefore, poids can be explicated in terms of "importance is weight" conceptual metaphor, which is motivated by a superordinate conceptual metaphor, that is, "properties are physical properties". 
Tوزْن (wazn), that is, "sobriety, wisdom" in "the mediator was of sobriety [weight in Arabic] and international reputation" (Table 1, Meaning 8). In this meaning extension, "weight" is mapped onto "wisdom", which is a quality of personality. Although French poids does not denote this meaning, the conceptual metaphor that motivates this semantic extension in Arabic وَزَ (wazn) exists in French but motivates the extension of another meaning, that is, "importance".

The term وَزْن (wazn) is also extended to "metre" (in poetry) in the example "He is credited with telling poetry and its metre" (Table 1, Meaning 3). In this instance, the measure of physical weight is mapped onto the measure (or metre) in versification. This projection can be understood in terms of "'physical weight/scale' is 'poetic scale"'. Within the ICM of "scale", the word وَزْ (wazn) (Table 1, Meaning 5) is also extended to "form (in morphology)". This means that $(w a z n)$ is also a grammatical category that has a similar form to the standard form, for example ضَرَبَ (daraba) (hit) corresponds to فَ (fala) (did) (the standard form) in conjugation or morphology. In this meaning extension, the measure of physical weight is mapped onto the grammatical form or measure; therefore, it is motivated by "physical weight/scale is linguistic/grammatical scale".

The above extensions of qَ (wazn) are not found in the French term poids. The contrast between the two terms is further evidenced by the meaning of poids which is extended to "burden, responsibility" in the example "... [these people] spend the day bent under the weight of affairs..." (Table 1, Meaning 10). This meaning denotes that "weight", a physical heaviness or heavy force (source domain) is mapped onto "burden" (target domain), which embodies feeling of heavy force. This semantic extension is motivated by "physical forces are psychological forces" conceptual metaphor.

Another difference in the meaning extension of "weight" in the two languages is the mixture of metonymy and metaphor available in وَزَ (wazn) but not in poids. In the example "...it turns into a mass of rock on the side of the mountain which no one can lift" (Table 1, Meaning 7), the Arabic term وَزْن is metonymically extended to "the side or shoe (literal meaning) of a mountain", which means that "weight", i.e., the physical property of a mountain shoe or side, stands for "mountain shoe". This is motivated by "physical property for mountain shoe" as "'mountain shoe' is 'part' of 'mountain"'; thus, it is motivated by "part" for "whole" metonymy. The use of "shoe" in Arabic to describe the side (of a mountain) also exhibits a metaphorical projection motivated by "a mountain is a person" metaphor. 
Yet another difference in the concept of "weight" in Arabic and French is the semantic extensions of poids motivated by the conceptual metonymy "physical property for vehicle, physical property for action/instrument" and "physical property/heaviness for weight unit". Firstly, the example "une voiture de location avait été aplatie par un poids lourd [a truck]" (Table 1, Meaning 11) suggests that poids is metonymically extended to "heavy goods lorry". This semantic projection can be explained in terms of "physical property for vehicle" metonymy. In other words, the physical attribute of a lorry, that is, heavy weight, stands for a lorry. The meaning of poids is also metonymically extended to "metal object of a determined mass for weighing things on a scale" (Table 1, Meaning 13). This semantic projection can be understood with regard to "physical property/heaviness for weight unit". Weight (i.e., heaviness) stands for a weight unit, that is, a mass of metal used to measure weight.

The above analysis suggests that the meanings of both terms poids are motivated by the conceptual metaphor of "properties are physical properties" (i.e., "importance is weight"). However, وَزْْن (wazn), unlike poids, underwent semantic projections that are motivated by other conceptual metaphors, namely, "physical weight/scale is poetic scale" and "physical weight/scale is linguistic/grammatical scale". On the other hand, the semantic extensions of the term poids are motivated by "physical forces are psychological forces" metaphor, which is not available in $($ gَزْن

The analysis also suggests that, in contrast to French poids, one of the meanings of وَزْن (wazn) is motivated by the "physical property for mountain shoe"

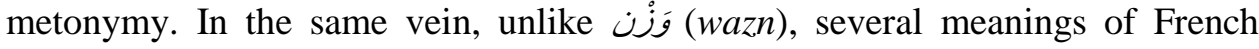
poids underwent semantic extensions motivated by conceptual metonymy, namely "physical property for vehicle, physical property for action/instrument" and "physical property/heaviness for weight unit".

Table 2 presents data on the five most common collocates of poids generated from the ArabiCorpus and the Concordancier-Corpus Français corpora respectively. As explained earlier, the frequency of collocates is the measure used in determining the prototypical meaning of each term. 
Table 2. The five most common collocates of $و َ$ (wazn) and poids

\begin{tabular}{|c|c|c|c|c|c|}
\hline \multicolumn{3}{|l|}{ ArabiCorpus } & \multicolumn{3}{|c|}{ Concordancier-Corpus Français } \\
\hline $\begin{array}{l}\text { Collocates in order of } \\
\text { frequency for وَزْن }\end{array}$ & 莺 & 导 & $\begin{array}{l}\text { Collocates in order of } \\
\text { frequency for poids }\end{array}$ & 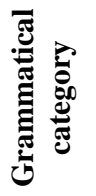 & 胥 \\
\hline $\begin{array}{l}\text { كيلو غر ام (kÊlËghrÉm) } \\
\text { (kilogram, with different } \\
\text { spelling and abbreviations as } \\
\text { this is a borrowed word) }\end{array}$ & $\mathrm{N}$. & 4363 & $\begin{array}{l}\text { énorme / immense } \\
\text { (enormous) / (immense) }\end{array}$ & Adj. & 73 \\
\hline $\begin{array}{l}\text { ثقيل (thaqÊl) } \\
\text { (heavy) }\end{array}$ & Adj. & 565 & $\begin{array}{l}\text { corps } \\
\text { (body) }\end{array}$ & N. & 67 \\
\hline $\begin{array}{l}\text { زيادة (ziyÉda) } \\
\text { (increase) }\end{array}$ & N. & 509 & $\begin{array}{l}\text { grand } \\
\text { (great) }\end{array}$ & Adj. & 59 \\
\hline $\begin{array}{l}\text { سياسي (siyÉsÊ) } \\
\text { (political) }\end{array}$ & Adj. & 385 & $\begin{array}{l}\text { sicles (shekels) } \\
\text { (weight and currency of } \\
\text { about six to } 12 \text { grams used in } \\
\text { ancient East) }\end{array}$ & $\begin{array}{l}\text { N. } \\
\text { Pl. }\end{array}$ & 56 \\
\hline $\begin{array}{l}\text { (baÏal) } \\
\text { (champion) }\end{array}$ & N. & 258 & $\begin{array}{l}\text { lourd } \\
\text { (heavy) }\end{array}$ & Adj. & 50 \\
\hline
\end{tabular}

Notes: N.: Noun; Pl.: Plural; Sing.: Singular; Adj.: Adjective. The data shows that the most frequent collocate of وَزْنَ is kilogram (referring to weight class, human weight, and weight). This suggests that the most prototypical meaning of 1 is "heaviness". The most frequent collocate of poids is enormous/immense, which means that the most prototypical meaning of poids is similar to "heaviness".

\section{The polysemy, prototypical meanings and metaphorical and metonymic extensions of}

The data on the polysemy of the nouns sita) and masse to refer to the concept "mass" were also generated from the ArabiCorpus and the Concordancier-Corpus Français. In total, eight different senses were derived for both terms, as presented in Table 3 (translation of the example texts in which the meanings occur are in square brackets).

The data show that (kutla) and masse share similar senses such as "lump" (Meaning 1) and "cluster" (Meaning 2). However, there are some major differences between them. For instance, only Arabic (kutla) has the sense of "bloc" (Meaning 3) while its French rendering masse can mean "majority" (Meaning 5), "an amount of money" (Meaning 7) and "a person who has a heavy body (fat) or is thickheaded" (Meaning 8). 
Table 3. The senses of S $_{\text {(kutla) }}$ and masse derived from the ArabiCorpus and the Concordancier-Corpus Français

\begin{tabular}{|c|c|c|}
\hline \multirow{2}{*}{ Senses } & \multicolumn{2}{|c|}{ Examples } \\
\hline & Arabic & French \\
\hline \multirow{3}{*}{$\begin{array}{l}\text { (1) "lump, large } \\
\text { amount of } \\
\text { substance (liquid } \\
\text { or gas by } \\
\text { extension)" }\end{array}$} & 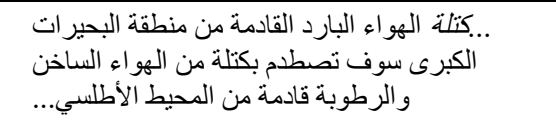 & \multirow{2}{*}{$\begin{array}{l}\text { Un rapide courant le poussa } \\
\text { alors dans une masse d'eau qui } \\
\text { mesurait sept à huit pieds de } \\
\text { profondeur. }\end{array}$} \\
\hline & $\begin{array}{l}\text {...kutlatu lhawÉ'i lbÉridi lqÉdimatu min } \\
\text { miÏlaqati lbúlayrÉti lkubrÉ sawfa } \\
\text { tâ̂IIadimu bikutlatin mina lhawÉ'I s- } \\
\text { sÉkhini wa r-ruÏËbati lqÉdimati mina } \\
\text { lmuÍ̂̂ÏI l'ä̈lasi... }\end{array}$ & \\
\hline & $\begin{array}{l}\text { [... the cold air mass coming from the } \\
\text { Great Lakes region will meet the mass of } \\
\text { warm moist air coming from the Atlantic } \\
\text { Ocean... }\end{array}$ & $\begin{array}{l}\text { [A fast current then pushed } \\
\text { him into a body of water which } \\
\text { measured seven to eight feet } \\
\text { deep] }\end{array}$ \\
\hline \multirow{3}{*}{$\begin{array}{l}\text { (2) "cluster"/"a } \\
\text { big quantity of } \\
\text { something" }\end{array}$} & و إذا نظرنا في العفة وجدنا كتلة من الأخلاق الرفيعة & \multirow{2}{*}{$\begin{array}{l}\text { En outre, il existe une masse } \\
\text { considérable d'aides à } \\
\text { l'emploi... }\end{array}$} \\
\hline & $\begin{array}{l}\text { wa idhÉ naĐarnÉ fê l'iffati wajadnÉ } \\
\text { kutlatan min l'akhlÉqi r-rafÊE`ati } \\
\text { l'Éliya... }\end{array}$ & \\
\hline & $\begin{array}{l}\text { [And if we consider chastity, we will } \\
\text { find a cluster of high morals...] }\end{array}$ & $\begin{array}{l}\text { [In addition, there is a } \\
\text { considerable amount of } \\
\text { employment aid...] }\end{array}$ \\
\hline \multirow{3}{*}{$\begin{array}{l}\text { (3) "bloc, a } \\
\text { group of } \\
\text { people that } \\
\text { share the same } \\
\text { opinion" }\end{array}$} & 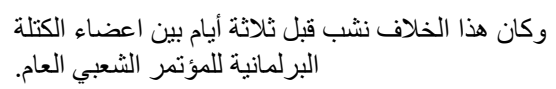 & \multirow{3}{*}{ NIL } \\
\hline & $\begin{array}{l}\text { wa kÉna hÉdhÉ lkhilÉfu nashaba qabla } \\
\text { thalÉthata ayyamin bayna a'İÉ'i lkutlati } \\
\text { lbarlamÉniyati lilmu'tamari sh-sha‘bi } \\
\text { l'Ém }\end{array}$ & \\
\hline & $\begin{array}{l}\text { [And this dispute broke out among the } \\
\text { members of the General People's } \\
\text { Congress parliamentary bloc three days } \\
\text { ago]. }\end{array}$ & \\
\hline \multirow{2}{*}{$\begin{array}{l}\text { (4) "a large } \\
\text { number of } \\
\text { people" }\end{array}$} & \multirow[t]{2}{*}{ NIL } & $\begin{array}{l}\text { Cette avalanche humaine, cette } \\
\text { masse d'individus... }\end{array}$ \\
\hline & & $\begin{array}{l}\text { [This human avalanche, this } \\
\text { mass of individuals...] }\end{array}$ \\
\hline
\end{tabular}


Table 3. (Continued)

\begin{tabular}{|c|c|c|}
\hline \multirow{2}{*}{ Senses } & \multicolumn{2}{|c|}{ Examples } \\
\hline & Arabic & French \\
\hline \multirow[t]{2}{*}{ (5) "majority" } & NIL & $\begin{array}{l}\text { Avec toutes les autres, elle avait } \\
\text { un intérêt commun au maintien } \\
\text { de la sujétion de la grande } \\
\text { masse ouvrière de la nation. }\end{array}$ \\
\hline & & $\begin{array}{l}\text { [With all the others, it had a } \\
\text { common interest in maintaining } \\
\text { the subjection of the great } \\
\text { majority of workers of the } \\
\text { nation] }\end{array}$ \\
\hline \multirow[t]{2}{*}{$\begin{array}{l}\text { (6) "a social } \\
\text { group or class, } \\
\text { the multitude" }\end{array}$} & NIL & $\begin{array}{l}\text { Oui, la télévision reste, n'en } \\
\text { déplaise aux esprits chagrins, un } \\
\text { formidable outil de } \\
\text { communication de masse, de } \\
\text { culture, et d'émancipation. }\end{array}$ \\
\hline & & $\begin{array}{l}\text { [Yes, television is, whether } \\
\text { whiners like it or not, a } \\
\text { formidable tool of mass } \\
\text { communication, culture, and } \\
\text { emancipation] }\end{array}$ \\
\hline \multirow[t]{2}{*}{$\begin{array}{l}\text { (7) "an amount } \\
\text { of money" }\end{array}$} & NIL & $\begin{array}{l}\text {...la gestion de la masse } \\
\text { monétaire ne leur appartient } \\
\text { plus. }\end{array}$ \\
\hline & & $\begin{array}{l}\text { [...the management of the } \\
\text { money supply no longer belongs } \\
\text { to them] }\end{array}$ \\
\hline \multirow{3}{*}{$\begin{array}{l}\text { (8) } \\
\text { "(Pejorative) a } \\
\text { person who has } \\
\text { a heavy body } \\
\text { (fat) or is } \\
\text { thickheaded" } \\
\text { (especially in } \\
\text { the expression } \\
\text { masse de } \\
\text { chair) }\end{array}$} & NIL & Il demeurait absolument \\
\hline & & $\begin{array}{l}\text { immobile, assis tout droit sur } \\
\text { son petit cheval qui se démenait } \\
\text { sous lui comme un furieux pour } \\
\text { porter cette masse. }\end{array}$ \\
\hline & & $\begin{array}{l}\text { [He stayed absolutely still, } \\
\text { sitting straight on his little horse } \\
\text { which struggled under him like a } \\
\text { mad to carry this heavy man] }\end{array}$ \\
\hline
\end{tabular}

The analysis of the semantic extensions of both (kutla) and masse suggests that both are similar in that they both underwent metonymic extension. However,

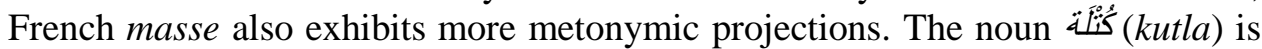
metonymically extended to "bloc, a group of people that share the same opinion" as "mass" (i.e., a large number of) stands for "bloc" (i.e., group with similar ideas and interests). Therefore, this semantic projection is motivated by "the whole for 
part" conceptual metonymy. However, the noun masse (a big number of [people]) is metonymically projected to "social group or class". In this context, "mass", which means a large number of, represents "class"; thus, this extension is motivated by "the whole for part" metonymy. The meaning of the noun masse is also metonymically extended to "a person who has a heavy body (fat) or is thickheaded", as shown in (8) in Table 3. In this context, "physical property" (i.e., large lump) stands for "people who are fat or thickheaded". However, this image is also motivated by "properties are physical properties" conceptual metaphor, as in the case of "thickheaded" (i.e., slow, mental quality).

Thus the projections of S $^{\text {(kutla) }}$ and masse are motivated by different conceptual metonymies. One of the meanings of (kutla) is motivated by "the whole for part" conceptual metonymy while one of the senses of masse is motivated by the metonymy "physical property/heaviness for people who are fat or thickheaded".

With regard to their prototypical meanings, the data on the most frequent collocations of each term generated from the ArabiCorpus and the Concordancier-Corpus Français suggest that they have different prototypes. The most frequent collocates of Arabic $(k u t l a)$ and French masse are presented in Table 4.

Table 4. The five most common collocates of

\begin{tabular}{|c|c|c|c|c|c|}
\hline \multicolumn{3}{|l|}{ ArabiCorpus } & \multicolumn{3}{|c|}{ Concordancier-Corpus Français } \\
\hline $\begin{array}{l}\text { Collocates in order of } \\
\text { frequency for كَّنَ }\end{array}$ & 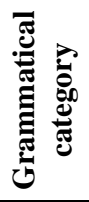 & 莺 & $\begin{array}{l}\text { Collocates in order of } \\
\text { frequency for masse }\end{array}$ & 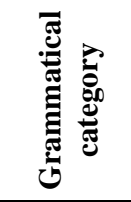 & 莺 \\
\hline $\begin{array}{l}\text { نيَابِيَة } \\
\text { (niyÉbia) parliamentary } \\
\text { (parliamentary, describing bloc): }\end{array}$ & Adj. & 1238 & $\begin{array}{l}\text { travailleuses, laborieuses, } \\
\text { ouvrières and populaires } \\
\text { (working) }\end{array}$ & Adj. & 195 \\
\hline جزَب (hizb) (party) & N. & 704 & grande (large) & Adj. & 116 \\
\hline $\begin{array}{l}\text { نُؤَاب (nuwwab) } \\
\text { (Members of Parliament or MPs) }\end{array}$ & $\begin{array}{l}\text { N./ } \\
\text { Pl. }\end{array}$ & 609 & $\begin{array}{l}\text { noire/s \& sombre/s } \\
\text { (black, dark) and (dark) }\end{array}$ & $\begin{array}{c}\text { Adj. } \\
\text { Sing./Pl. }\end{array}$ & 115 \\
\hline وطنية (waÏaniyya) (national) & Adj. & 405 & People (people) & N./Pl. & 89 \\
\hline $\begin{array}{l}\text { وَاحَد (wÉlida) } \\
\text { (single, describing bloc) }\end{array}$ & Adj. & 388 & $\begin{array}{l}\text { enorme } \\
\text { (enormous) }\end{array}$ & Adj. & 59 \\
\hline
\end{tabular}

Notes: N.: Noun; Pl.: Plural; Sing.: Singular; Adj.: Adjective. The data show that the most common collocate of is "parliamentary", suggesting that the most prototypical meaning of is is "bloc", while the most frequent collocate of masse is "working", indicating that the most prototypical meaning of masse is "class". 


\section{Discussion}

The data on polysemy, prototype and extensions of the concepts of "weight" and "mass" in Arabic and French suggest that there are similarities and differences. With regard to the concept of "weight", both terms the meanings of "weight", "importance", "weight class" and "measuring weight of an individual's body". Yet they differ in that only وََّ can be used to refer to "metre (in poetry)", "form (in morphology)", "wisdom" and "a side of a mountain"; and only poids have the meanings "pressure (of atmosphere)", "heavy goods lorry" and "the central energy storage device (of a clock)". Despite this difference, the analysis of their most common collocates suggests that they have similar prototypes namely "heaviness" (as a concrete physical concept).

In terms of semantic extensions, the senses of both terms are motivated by the conceptual metaphor of "properties are physical properties". However, only (wazn) underwent semantic projections that are motivated by "physical weight/scale is poetic scale" and "physical weight/scale is linguistic/grammatical scale" conceptual metaphors. Similarly, only the term poids is motivated by "physical forces are psychological forces" metaphor. As regards metonymy, interestingly the Arabic term وَزْن (wazn) is projected by motivation of "physical property for mountain shoe" metonymy while the French term poids underwent semantic extensions motivated by conceptual metonymy, that is, "physical property for vehicle", "physical property for action/instrument" and "physical property/heaviness for weight unit".

As far as the concept "mass" is concerned, Arabic (kutla) and French masse are similar in the meanings of "lump" and "cluster". However, as shown earlier, they differ in other senses. Only the Arabic term possesses the meaning "bloc" or "group", while the French masse can denote "majority", "an amount of money" and "a person who has a heavy body or is thickheaded". With regard to prototypical meaning, the prototype of $(k u t l a)$ is "bloc" given that its most frequent collocate is "parliamentary" (parliamentary, describing bloc), while the prototype of masse is "class" as its most frequent collocate is "working". The analysis also shows that the projections of $(k u t l a)$ and masse are motivated by different conceptual metonymies. One of the meanings of by "the whole for part" conceptual metonymy while one of the meanings of masse is motivated by the metonymy "physical property/heaviness for people who are fat or thickheaded".

Another important point is that most prototypical meaning for the concept "weight" in Arabic is associated with heaviness, specifically units like kilograms, as in the example provided in (1) Table 1, that is, 
(its [computer] weight is roughly one and a half kilograms), where "kilogram" refers to weight. However, in Science, a kilogram is a unit of mass. Weight as a scientific term is a measure of the attraction of the earth for a given mass. French poids is also linguistically measured in terms of units like kilograms and pounds; therefore, like Arabic

This may lead to learners' confusion in the science classroom, irrespective of whether they are Arabic or French speaking as confusing "weight" with "mass" happens in both languages. In fact, Western learners, including English learners, may also face similar challenges due to the dichotomy between everyday speech and scientific terminology (see Strömdahl 2007; Duit and Kesidou 1988). Nevertheless, this issue may be more challenging for learners whose first language is Arabic, in contrast to French native speakers. This is mainly because French is a Western language and Newton's use of "mass" is mostly associated with the traditional usage of Western languages (Kawasaki 2005).

The differences found between Arabic and French concepts of "weight" and "mass" as evident above may create difficulties for learners, especially Arab learners in countries where the medium of instruction is French. The cognitive load required by these learners who are non-native speakers of French to understand the concepts would naturally be more than that required by native speakers. This is not just because of their pre-existing knowledge of the words but also their cultural understanding and conceptualisation. The existence of these differences supports the notion of linguistic incommensurability and the need for learners to understand a concept with reference to their own knowledge and experience, which is bodily and culturally grounded before they are taught the scientific concepts. For learners who are learning science in another language, the polysemy of the concept should be made known to them. Armed with such knowledge, learners may be more aware of the complexity of the concepts and be more successful in attaining the scientific meaning.

Overall, the similarities identified support the linguistic universals (in the present study across Arabic and French) while the differences found support the view of linguistics and cultural relativism. They also bring to mind the point that was raised earlier about cultural conceptualisations and how they are negotiated and renegotiated over time. The renegotiation that takes place within a culture may cause the emergence of senses and extensions that are culture-specific. This can further complicate the understanding of such terms in learning the words in the context of science. 


\section{Conclusion}

Despite the dominance of the Western perspective of science, cultural conceptualisations that are entrenched in the local form must be given due attention. Science educators should be cognizant of the polysemous nature of common terms such as "weight", "temperature", "heat", "force", etc. that are used as scientific terminologies. The different senses of terms ranging from everyday language to scientific terminology must be communicated to the learners to raise their linguistic awareness and to prevent them from misunderstanding scientific terms and confusing scientific meanings with common meanings and use. This must be done to facilitate learners' success in understanding scientific concepts from the Western perspective of science as modern science is the outcome of the contributions by Western scientists, i.e. Western heritage (Kawasaki 1996). This will also help learners to enrich their knowledge of the concepts and conceptualisations based on context and use.

\section{Note}

1. According to Saussure (1959), the linguistic sign is a mental unit consisting of a signifié (concept) and signifiant (acoustic image). The word is a linguistic sign.

\section{References}

Aikenhead, G. 2001. Integrating western and aboriginal sciences: Cross-cultural science teaching. Research in Science Education 31(3): 337-355, https://doi.org/10.1023/ A:1013151709605.

Aikenhead, G. and Ogawa, M. 2007. Indigenous knowledge and science revisited. Cultural studies of Science Education 2(3): 539-620, https://doi.org/10.1007/ s11422-007-9067-8.

Aranador, L. C. 2005. Language culture incommensurability in science in the Philippine education context. In Southeast Asian and Japanese cultural influences on the understanding of scientific concepts: Proceedings of the Japan Foundation Intellectual Exchange Project, eds. Loo, S. P. and Sarmiento, C. Q., 118-122. Pulau Pinang, Malaysia: RECSAM-SEAMEO.

Boas, F. 1922. Handbook of American Indian languages. Bureau of American Ethnology Bulletin 40: Part 2. Washington: Government Printing Office.

. 1911. Handbook of American Indian languages. Bureau of American Ethnology Bulletin 40: Part 1. Washington: Government Printing Office.

Bowker, L. and Pearson, J. 2002. Working with specialized language: A practical guide to using corpora. London: Routledge, https://doi.org/10.4324/9780203469255.

Croft, W. and Cruse, D. A. 2004. Cognitive linguistics. Cambridge: Cambridge University Press, https://doi.org/10.1017/CBO9780511803864.

Duit, E. and Kesidou, S. 1988. Students' understanding of basic ideas of the second law of thermodynamics. Research in Science Education 18(1): 186-195, https://doi.org/10.1007/BF02356594. 
Fillmore, C. 1982. Frame semantics. In Linguistics in the morning calm, ed. The Linguistic Society of Korea, 111-138. Seoul: Hanshin Publishing Company.

Geeraerts, D. 2006. Where does prototypicality come from? In Words and other wonders: Papers on lexical and semantic topics, eds. Geeraerts, D., Dirven, R., Taylor, J. R. and Langacker, R. W., 27-47. Berlin: Mouton de Gruyter, https://doi.org/10.1515/ 9783110219128.1.27.

Hampton, J. A. 2006. Concepts as prototypes. Psychology of Learning and Motivation 46: 79-113, https://doi.org/10.1016/S0079-7421(06)46003-5.

Ho-Abdullah, I. and Hashim, R. S. 2009. A cognitive semantics analysis of Alam (nature) in Malay. European Journal of Social Sciences 8(1): 140-151.

Hudson, R. A. 1996. Sociolinguistics. Cambridge: Cambridge University Press, https://doi.org/10.1017/CBO9781139166843.

Kawasaki, K. 2007. Towards worldview education beyond language-culture incommensurability. International Journal of Science and Mathematics Education 5(1): 29-48, https://doi.org/10.1007/s10763-005-9023-6.

. 2005. Toward restoration of subjectivity in science education: How to resolve language-culture incommensurability. In Southeast Asian and Japanese cultural influences on the understanding of scientific concepts: Proceedings of the Japan Foundation Intellectual Exchange Project, eds. Loo, S. P. and Sarmiento, C. Q., 15-54. Pulau Pinang, Malaysia: RECSAM-SEAMEO.

2002. A cross-cultural comparison of English and Japanese linguistic assumptions influencing pupils' learning of science. Canadian and International Education 31(1): 19-51.

. 1999. A deductive description of cultural diversity of "observation" in science education. Journal of Science Education in Japan 23(4): 258-270.

1996. The concepts of science in Japanese and Western education. Science and Education 5(1): 1-20.

Lahlou, H. and Hajar Abdul Rahim. 2013. A cognitive linguistic analysis of the concept TEMPERATURE in English and Arabic. Special issue on translation, Arab World English Journal 2: 118-128.

Lakoff, G. 1987. Women, fire, and dangerous things: What categories reveal about the mind. Chicago: The University of Chicago Press, https://doi.org/10.7208/ chicago/9780226471013.001.0001.

Lakoff, G. and Johnson, M. 2003. Metaphors we live by. London: The University of Chicago Press.

Langacker, R. W. 1987. Foundations of cognitive grammar, vol. 1: Theoretical prerequisites. Stanford, CA: Stanford University Press.

Loo, S. P. 2005. The two cultures of science: On language-culture incommensurability concerning "nature" and "observation". In Proceedings of the Japan Foundation intellectual exchange project: Southeast Asian and Japanese cultural influences on the understanding of scientific concepts, eds. Loo, S. P. and Sarmiento, C. Q., 1-14. Pulau Pinang, Malaysia: RECSAM-SEAMEO.

$\mathrm{Ng}, \mathrm{K}$. T. and Soo, B. N. 2006. Exploring factors contributing to science learning via chinese language. Kalbu Studijos 8: 50-57.

Ogawa, M. 1998. A cultural history of science education in Japan: An epic description. In Socio-cultural perspectives on science education: An international dialogue, vol. 
4, ed. Cobern, W. W., 139-161. The Netherlands: Kluwer Academic Publishers, https://doi.org/10.1007/978-94-011-5224-2_8.

Rosch, E. 1975. Cognitive representations of semantic categories. Journal of Experimental Psychology: General 104(3): 192.

1973. Natural categories. Cognitive Psychology 4(3): 328-350.

Rosch, E. R. 1978. Principles of categorization. In Cognition and categorization, eds. Rosch, E. R. and Lloyd, B. B., 27-48. Hillsdale, NJ: Erlbaum.

Sapir, E. 1921. Language: An introduction to the study of speech. New York: Harcourt Brace.

Saussure, F. D. 1959. Course in general linguistics, trans. Baskin, W. New York: McGraw-Hill Book.

Sharifian, F. 2011. Cultural conceptualisations and language: Theoretical framework and applications. Amsterdam/Philadephia: John Benjamins.

Strömdahl, H. 2007. Critical features of word meaning as an educational tool in learning and teaching natural sciences. In The 13th international conference on thinking, 181-218. Sweden: Linköping University Electronic Press.

Whorf, B. L. 1956. Language, thought, and reality: Selected writings of Benjamin Lee Whorf. Massachusetts, USA: MIT Press. 